Journal of Southeast Asian Human Rights, Vol. 4 Issue. 1 June 2020 pp.271 - 305

doi: 10.19184 /iseahr.v4i1.12810

(C) University of Jember \& Indonesian Consortium for Human Rights Lecturers

\title{
A Comparative Analysis of the Status of Homosexual Men in Indonesia and the Philippines
}

\author{
Adihartono, W. \\ École des Hautes Études en Sciences Sociales (EHESS) \\ Email: wisnuadi.reksodirdjo@gmail.com \\ Ellisiah Uy Jocson \\ Independent Researcher \\ Email: ellisiahjocson@gmail.com
}

\begin{abstract}
Gender related discrimination has increased pervasively, especially as the fight for equality and acceptance takes center stage in the past few years. Women persistently demand the right to stand equally with men, and likewise, the Lesbian, Gay, Bi-Sexual, Transgender, Queer and Intersex Community (LGBTQI) ${ }^{1}$ seek the same equity. However, responses to gender and sexuality issues vary greatly across the world. The LGBTQI population is also difficult to determine given the intolerance of some Countries towards this community. On the topic of homosexuality, attitudes and presumptions prevail ${ }^{2}$ and act as barriers in acceptance of the 'gay' community. These obstacles hail from a multitude of concerns, spanning the areas of culture, religion and ethnicity, amongst others. This study seeks to analyze and determine the treatment of homosexual men in two multicultural countries: Indonesia and the Philippines. Repeated reports of gay suppression in Indonesia are a stark contrast to the seemingly high tolerance that gay people enjoy in the Philippines. This paper outlines the causes of these opposing treatments for gay communities in Indonesia and the Philippines.
\end{abstract}

Keywords: Gay, Gayness, Homosexuality, Multiculturalism, Tolerance, Religion.

1 The Office of Lesbian, Gay, Bisexual, Transgender, Queer \& Intersex Life, "Definitions”, online: Vanderbilt University <https://www.vanderbilt.edu/lgbtqi/resources/definitions>, Nashville Tenessee 37240 .

2 Winnie Mucherah, Elizabeth Owino \& Kaleigh McCoy, "Grappling with the issue of homosexuality: perceptions, attitudes, and beliefs among high school students in Kenya” (2016) 9 Psychology Research and Behavior Management 253-262. 


\section{INTRODUCTION}

Homosexuality, is commonly defined as being "attracted to members of one's own sex."3 People categorized as homosexual have been historically abhorred by society due to a number of factors. These factors, however, lead to the very nature of homosexuality that challenges the norms of traditional sexual orientation and culture. Numerous studies have been undertaken intending to understand homosexual people. The topic is currently considered a "hot issue" due to superimposed implications and subsequent conflicts which arise as LGBTI people and communities seek social integration.

Globally, lesbian (L), gay (G), bisexual (B), and transgender (T) people and-other gender and sexual minorities; experience criminalization, systemic violence and discrimination in employment and health care; a lack of legal recognition concerning their families and partnerships; and restricted freedom of expression, association and peaceful assembly. ${ }^{4}$ In Southeast Asia, same-sex sexual acts are criminalized under the law in Malaysia, Singapore and Brunei Darussalam, as well as South Sumatra and the Aceh province in Indonesia. ${ }^{5}$ There is only one country in the region that protects its citizens from workplace discrimination on the basis of gender identity or sexual orientation through national law and that is Thailand since $2015 .{ }^{6}$ Despite the often remarkable cultural valuation of kinship, family ties and marriage, nowhere in Southeast Asia legally recognizes same-sex partnerships and joint adoption by lesbian and gay couples remains a legal impossibility. ${ }^{7}$ Although gender reassignment surgery is available in Thailand, transgender citizens cannot change their previously assigned gender in official documents and remain vulnerable to violence, harassment and discrimination.

One component of this social ecology faced by sexuality and gender minorities is public opinion. ${ }^{8}$ Social attitudes may range from affirmation and acceptance (homopositivity) to disapproval, denial and denigration (homonegativity). Public opinion

3 S Dowshen, "Sexual Orientation", (2018), online: The Nemours Foundation <<https://kidshealth.org/en/parents/sexual-orientation.html〉>.

4 OHCHR, Born free and equal: Sexual Orientation and gender identity in international human rights law (New York: United Nations, 2012).

5 State sponsored homophobia 2016: A world survey of sexual orientation laws: Criminalisations, protection and recognition, by A Caroll (Geneva: International Lesbian, Gay, Bisexual, Trans and Intersex Association, 2016).

6 Eric Julian Manalastas et al, "Homonegativity in Southeast Asia: Attitudes Toward Lesbians and Gay Men in Indonesia, Malaysia, the Philippines, Singapore, Thailand, and Vietnam” (2017) 17:1 AsiaPacific Social Sciences Review 25-33.

7 Douglas Sanders, "Recognizing Same-Sex Relationships in Thailand" (2013) 6:1 CMU Journal of Law and Social Sciences 27-55.

8 Gregory M Herek, "Beyond 'homophobia': Thinking about sexual prejudice and stigma in the twenty-first century" (2004) 1:2 Sexual Research \& Social Policy 6-24; Gregory M Herek, "Confronting sexual stigma and prejudice: Theory and practice" (2007) 63 Journal of Social Issues 905-925; Gregory M Herek \& Kevin A McLemore, "Sexual Prejudice” (2013) 64:1 Annual Review of Psychology 309-333. 
has been used as a core component in popular metrics measuring a country's level of friendliness to LGBTI people such as the Gay Happiness Index. ${ }^{9}$

\section{Global Demographics of the Gay Community}

Who exactly is included in the homosexual community or more specifically, the Lesbian, Gay, Bisexual, Transgender, Queer and Intersex (LGBTQI) community, is difficult to determine. Most demographic research focusing on Lesbian, Gay, Bisexual and Transgender (LGBT) populations has relied on the analysis of US Census Bureau data for identification of cohabiting same-sex couples. ${ }^{10}$ In the last decade, several large national population-based surveys included questions measuring sexual orientation. Unfortunately, these surveys do not include direct measurement of gender identity. The availability of multiple surveys allows for the development of a more thorough and complete picture of demographic similarities and distinctions between LGBT individuals and their non-LGBT counterparts in the United States. ${ }^{11}$ References to LGB (when only sexual orientation was collected) or LGBT (when LGBT when sexual orientation and gender identity was collected) are used, as appropriate, when referring to respondents from individual surveys. ${ }^{12}$ The analysis focuses on four national population-based surveys: ${ }^{13}$

1. National Survey of Family Growth (NSFG): 2006-2010

2. General Social Survey (GSS): 2008, 2010, 2012

3. National Health Interview Survey (NHIS): 2013

4. Gallup Daily Tracking Survey (Gallup): 2014

In a review of population-based surveys conducted between 2005 and 2009 in the US, Gates (2011) found that the estimated prevalence of LGB/T individuals among adults ranged from 1.7 percent to 5.6 percent with an average of approximately 3.5 percent identifying as LGB and, in an assessment of two State-level surveys, approximately 0.3 percent of adults identifying as transgender. Amongst all adults, the proportion that identified as LGB/T varied from 2.2 percent reported by NHIS to 4.0 percent in the Gallup data, implying that there are between 5.2 and 9.5 million adults in the United States that identified as LGB/T. In all surveys, the proportion of those aged 18-44 who identified as LGB/T was higher than the proportion that did so among all adult groups. Estimates of LGB/T prevalence in this age group were similar in the GSS

9 Richard Lemke, Tobias Tornow \& PlanetRomeocom, Gay Happiness Monitor - Results overview from a global survey on perceived gay related public opinion and gay well-being (Mainz: Johannes Gutenberg University, 2015).

10 Gary J Gates \& Jason Ost, The Gay and Lesbian Atlas (Washington, D.C: Urban Institute Press, 2004).

11 Gary J Gates, "LGB/T Demographics: Comparisons among population-based surveys" (2014) Williams Institute: UCLA School of Law.

12 Gates \& Ost, supra note 10.

13 Gates, supra note 11. 
(4.2 percent) and NSFG (4.1 percent) data sets. The NHIS estimate was lowest at 2.5 percent and the Gallup estimate was highest at 5.6 percent. The proportion of adults identifying as either lesbian or gay were quite consistent across surveys. Amongst adults, the NHIS and GSS found 1.6 percent and 1.4 percent identified as such, respectively. For adults aged 18-44, the variation among three surveys (NSFG, NHIS and Gallup) ranged from 1.5 percent to 1.8 percent. ${ }^{14}$

All four surveys showed much more variation in the estimated proportion of adults identifying as bisexual. That estimate was lowest as reported by NHIS, at 0.6 percent among all adults, compared to 1.6 percent reported by GSS. Among those aged 18-44, the proportion of bisexual individuals was 1.0 percent in the NHIS compared to 2.6 percent in the GSS. ${ }^{15}$ Cumulatively, the population may be termed a sub-minority. A rise in this population is expected to continue, implying that more and more people are being labeled, ridiculed and facing various acts of discrimination.

\section{Determining Homosexuality}

The Kinsey scale, developed in the 1940s by Dr. Alfred Kinsey, is one of the first attempts of the early 1900s to understand homosexuality. The study in which the scale was developed showed that people do have definitive leanings on sexuality, and these are gradated into nine areas. The study implies that everyone has a tendency to be homosexual, with variations in preference dictating the actual category into which an individual falls. Dr. Kinsey, at his time, also declared that 10 percent of the world population was gay. ${ }^{16}$ However, this number is largely disputed and considered flawed as the characteristics surrounding homosexuality extend beyond the traditional outlook of sexual intercourse between people of the same sex. ${ }^{17}$ Studies such as these also imply a "normative" aspect of sexual deviation. Such preferences exist for many individuals, thereby interpreting sexual deviation as "regular" but not totally and immediately acceptable. Intolerance spans from many spheres disavowing traditional characteristics of homosexuality, such as religious beliefs, age and general social tolerance.

Although the word "homosexuality" is no longer affiliated with the word "disease", the word nonetheless continues to carry a negative meaning. Guidelines for the use of the term homosexual issued by the BBC in one of its broadcasts in August 2002 stated that some people believe the word 'homosexual' has negative overtones and even demeaning ones and most homosexual men and women prefer the words 'gay' and

14 Ibid.

15 Ibid.

16 J Robison, "What Percentage of the Population is Gay?", (2002), online: Gallup Inc <https://news.gallup.com/poll/6961/what-percentage-population-gay.aspx>.

17 D Spiegelhalter, "Is 10\% of the Population Really Gay?", (2015), online: $<$ https://www.theguardian.com/society/2015/apr/05/10-per-cent-population-gay-alfred-kinseystatistics $>$. 
'lesbian.' 18 There is also a preference over the use of the word 'gay' as an adjective rather than as a noun, as the latter is deemed unacceptable, while the term 'homosexual is both acceptable as a either an adjective or noun as it is seen as applicable to both men and women. ${ }^{19}$ For purposes of clarity, this study will use the term gay to refer to homosexual men for better representation as indicated in the LGBTQI spectra.

The great leap in development for homosexual liberation began in the 1960s, mainly in the United States. From these events, the use of the term 'gay' began to spread. The adoption of this term has represented an effort to move away from the medical model and constitute an identity based on pride of difference. ${ }^{20}$ In addition, 'gay' is a more neutral term which can designate a specific and positive culture. ${ }^{21}$ Hayes (1976) argued the statement "I am gay" has an important element of self-definition. ${ }^{22}$ "Homosexual" does not comply with the need for self-definition, because the term was imposed upon the community by doctors and other "scientists" who have generally been unsupportive. Donovan (1992) also argued that "homosexual" defines a behavior, whereas gay defines an acceptance of the behavior, a mind-set, by an individual. ${ }^{23}$ "Gay" describes a way of life. It must be noted however that 'gay' as a noun refers to homosexuals who share social and psychological attributes and should not be mistaken as otherwise. ${ }^{24}$ Therefore, to be gay is to be comfortable with oneself. Being gay is above all a commitment to identity, as if to say, "I am gay," "it is who I am," and "that is what I label myself", connoting agency in identity. ${ }^{25}$ At present, "Queer Studies" have been dedicated to studies on homosexuality's history, nature, sociology, anthropology and so on. Their authors set out to demonstrate homosexuals were regular people, just like any other. ${ }^{26}$

\section{HOMOSEXUALITY AS A MINORITY IN INDONESIA AND IN THE PHILIPPINES}

According to research, members of the LGBT Community face discrimination, social stigma and denial of civil and human rights. ${ }^{27}$ In Asia alone, there are 12 countries that

18 Brian Whitaker, Unspeakable Love (London: SAQI, 2011).

19 Ibid.

20 Marina Castañeda, Comprendre l'homosexualité: Des clés, des conseils pour les homosexuels, leurs familles, leurs thérapeutes (Paris: Robert Laffont, 1999).

21 Elisabeth Badinter, XY : De l'identité masculine (Paris: Odile Jacob, 1992).

22 J J Hayes, “Gayspeak” (1976) 52 Quarterly Journal of Speech 256-266.

23 James M Donovan, "Homosexual, gay, and lesbian: defining the words and sampling the populations.” (1992) 24:1 Gay and Lesbian Studies (Journal of homosexuality) 27-47.

24 Henry L. Minton (Eds.), Ibid.

25 Savin-Williams, Ritch C. (2005). The New Gay Teenager. Cambridge: Harvard University Press

26 Ritch C Savin-Williams, The New Gay Teenager. (Cambridge: Harvard University Press, 2005).

27 Office of Disease Prevention and Health Promotion (2019) "Lesbian, Gay, Bisexual and Transgender Health”.U.S. Department of Health and Human Services, 200 Independence Ave. S.W. Washington, DC 20201. Retrieved from: <https://www.healthypeople.gov/2020/topicsobjectives/topic/lesbian-gay-bisexual-and-transgender-health\#one> 
criminalize consensual same-sex acts. ${ }^{28}$ Discrimination against the gay community and its members are associated with high rates of psychiatric disorders. ${ }^{29}$ Prevalence of discrimination also leads to high rates of suicide for gay youths, affirming how environment plays a key role in the social functioning of identified and self-identified gay people. ${ }^{30}$ Discrimination against gay people is notably prevalent in regions that strictly follow specific religious beliefs as legal guidelines, such as Islamic Sharia $\mathrm{Law}^{31}$ or passages $^{32}$ from the Christian Bible. ${ }^{33}$ In Indonesia, the law stigmatizes LGBT people and restrictions greatly inhibit their participation in mainstream society. ${ }^{34}$ Similarly, such restrictions exist in the Philippines, whereby a largely Catholic population prevents legislation that will protect same-sex couples, ${ }^{35}$ which is in contradiction of the 73 percent popular acceptance rate for homosexual people that the Philippines has garnered. The Philippine government, led by President Rodrigo Duterte opposed ${ }^{36}$ the legalization of same-sex marriage, creating yet another blockade for LGBT advocates. ${ }^{37} \mathrm{~A}$ study by Manalastas et al determined that large populations of Southeast Asians reject gay men as neighbors. ${ }^{38}$ Indonesia was ranked highest in homonegativity, garnering 66 percent, and the Philippines relatively lower, garnering 28 percent. ${ }^{39}$

Both countries' national interests and development plans fail to incorporate LGBT friendly schemes. In terms of tourism, the region is yet to place equal treatment for LGBT people, with Muslim countries being indifferent to the possibility of

28 A Langlois et al, "LGBT Rights in Southeast Asia: One Step Forward, Two-Steps Back?" (2017) IAFOR Journal of Asian Studies, online: <http://iafor.org/archives/journals/iafor-journal-of-asianstudies/10.22492.ijas.3.1.01.pdf>.

29 Katie A McLaughlin, Mark L Hatzenbuehler \& Katherine M Keyes, "Responses to Discrimination and Psychiatric Disorders Among Black, Hispanic, Female, and Lesbian, Gay, and Bisexual Individuals" (2010) 100:8 American Journal of Public Health 1477-1484.

30 Mark L Hatzenbuehler, "The Social Environment and Suicide Attempts in Lesbian, Gay, and Bisexual Youth” (2011) 127:5 Pediatrics 896-903.

31 LGBT Rights in South Asia: What Next? , by HY Yee (Salzburg, Austria: Salzburg Global Seminar, 2019).

32 Robyn Whitaker, “Same Sex Marriage: What Does the Bible Really Have to Say?”, Australian Broadcasting Corporation (2017), online: <https:/www.abc.net.au/news/2017-08-23/same-sexmarriage-what-bible-has-to-say-robyn-whitaker/8831826>.

33 K Gander, "Muslims, Jews and Christians on Being LGBT and Believing in God", (2017), online: The Independent <https:/www.independent.co.uk/life-style/love-sex/lgbt-muslims-christians-jewsstonewall-beliefs-god-faith-role-models-lifestyle-gay-lesbians-trans-a7666846.html > .

34 NQAPIA, "Fact Sheet: The State of LGBTQ Rights in Asia and the Pacific", (12 February 2018), online: National Queer Asian Pacific Islander Alliance <https://www.nqapia.org/wpp/state-of-lgbtqrights-in-asia-and-the-pacific/>.

35 Ibid.

36 C Conde, "Philippines Should Adopt Same-Sex Marriage", (20 March 2017), online: Human Rights Watch<https://www.hrw.org/news/2017/03/20/philippines-should-adopt-same-sex-marriage>.

37 R Jennings, "These Asian Countries are the Most Likely to Follow in Taiwan's LGBT Rights Footsteps" Forbes (2017), online: <https://www.forbes.com/sites/ralphjennings/2017/05/25/aftersame-sex-marriage-in-taiwan-spotlight-turns-to-this-asian-country/\#561a39613b4f>.

38 Manalastas et al, supra note 6.

39 Ibid. 
criminalizing LGBT people and activities. ${ }^{40}$ These findings also show that LGBT views vary in-country; Bali, Indonesia and Manila, Philippines are identified as LGBT friendly cities. ${ }^{41}$ However, other sources express that the Philippines is only LGBT friendly on paper, arguing that a homosexual person may be tolerated if there are imposed prohibitions. For example, a gay person is tolerated as long as they are comic or humorous, but not if they choose to be something else, especially when their rights and other important matters are discussed..$^{42}$

These reports are indicative of the possibility of future divisions in the region. ${ }^{43}$ The disparity in acceptance levels posits disparities in human rights promotion as well as social integration. Beyond the clout of various components particularly religious practices and beliefs, culture and politics - lies a degree of uncertainty for the future for homosexual minorities in the two countries.

\section{Rejection}

Openness is largely absent where homosexuality is concerned. People vary in their degree of openness and acceptance for homosexual people. This is true in terms of the rise in global acceptance of homosexuals from 1980, which saw an increase in 80 out of 141 countries. ${ }^{4}$ This acceptance increase is paired with a decline in 46 out of 141 countries, and showed no change in 15 countries from the same set. ${ }^{45}$ Changing acceptance levels globally, illustrates there is division in basic acceptance of homosexuals in mainstream society. Alarmingly, these countries self-amplify their current status, wherein accepting countries become more accepting and rejecting countries become more rejecting. ${ }^{46}$ The sphere of rejection has been found to cause stress and anxiety among the homosexual minority resulting from bullying, discrimination and civil rejection. ${ }^{47}$ This pushes homosexuals to lead lives of hyper vigilance, bearing pressure to

40 C De Wilde, “LGBT Tourism and Inclusion in Southeast Asia: A Divided Future?”, (2018), online: <https://thediplomat.com/2018/06/lgbt-tourism-and-inclusion-in-southeast-asia-a-divided-future/>.

41 J Marcus, "5 LGBT-Friendly Cities in South-East Asia” Goats on the Road.”, (2018), online: <https://www.goatsontheroad.com/lgtb-friendly-southeast-asia/>.

42 P Chiu, "Pinoys are gay friendly? Only on paper, says LGBT activist", (2013), online: GMA News Online <https:/www.gmanetwork.com/news/news/nation/312328/pinoys-are-gay-friendly-only-onpaper-says-lgbt-activist/story/?fbclid=IwAR3U6vPn7Mf18VqdFX4uWu4kq5tmSqDJOIYSstGo1uTpFtm9WiItp6dJ1Q>.

43 De Wilde, supra note 40.

44 Flores, A. \& Park, A. (2018). "Polarized Progress: Social Acceptance of LGBT People in 141 Countries, 1981 to 2014". The Williams Institute. UCLA School of Law. Retrieved from: < https://williamsinstitute.law.ucla.edu/wp-content/uploads/Polarized-Progress-April-2018.pdf>

45 Ibid.

46 Ibid.

47 A Flores \& A Park, "Polarized Progress: Social Acceptance of LGBT People in 141 Countries, 1981 to 2014" (2018) The Williams Institute, UCLA School of Law, online: <https://williamsinstitute.law.ucla.edu/wp-content/uploads/Polarized-Progress-April-2018.pdf>. 
conceal their identity, experiencing depression and in some cases committing suicide. ${ }^{48}$ Rejection is rampant due to different sexual orientations and needs with acceptance regarded being conditional, as is the case in the Philippines..$^{49}$ It is further heightened by the high tendency of homosexuals to gain sexually transmitted diseases, ${ }^{50}$ such as syphilis (epidemiologically linked to men who have sex with men), ${ }^{51}$ presence of HIV in gay bathhouses ${ }^{52}$ obtained through frequent changes in partners, exposure to anonymous contacts, and anal intercourse..$^{53}$ There is no absence of activism for gay rights in the region, however, variations in stances between the members of the community fail to offer a minimal cushion for the effects of discrimination and abuse given their contradictory nature. ${ }^{54}$ The exclusion of the gay community is thereby traced in their ambiguous rights, as well as the repeated intolerance towards sexual orientation and its associated characteristics in both countries.

In Indonesia, rejection of the gay community is common for myriad reasons. Firstly, many people believe that same-sex relationships are forbidden by God or religion, therefore LGBT people do not need to be protected or empowered. Belief in homosexuality as a religious transgression is still quite prevalent in society and in State policy, resulting in violence that is often considered necessary or permissible because it indicates that the victims are on a path not condoned by God. ${ }^{55}$ Secondly, many people believe that being LGBT is a lifestyle that is avoidable if a person wishes to do so. This lifestyle is viewed as destructive and in opposition to existing norms. Sexual relations such as sodomy and the general lifestyle of gay people is viewed as a strange and abnormal way to live. Since lifestyle is a choice, LGBT issues are not seen as a transnational human rights issue but as a personal choice. ${ }^{56}$ Thirdly, there is a misconception that the LGBT community practices a lifestyle associated with glamour, thereby an LGBT person cannot hail from poor sectors of society which eliminates the need for State policy protecting LGBT people. Fourthly, LGBT people are secretive of their sexual orientations due to shame or family-related concerns. They hide their attraction towards the people they love, unlike their heterosexual counterparts. Thus, the

48 Ibid.

49 Being LGBT in Asia: The Philippines Country Report, by UNDP \& USAID (Bangkok, 2014).

50 R N Thin \& D M Smith, "Some characteristics of homosexual men" (1976) 52:3 The British Journal of Venereal Diseases (Sexually Transmitted Infections) 161-164.

51 M Solomon \& K Mayer, "Evolution of Syphilis Among Men Who Have Sex with Men" (2015) 12:2 Sexual Health 96-102.

52 Lance M Pollack et al, "Presence of an HIV Testing Program Lowers the Prevalence of Unprotected Insertive Anal Intercourse inside a Gay Bathhouse among HIV-negative and HIV-unknown Patrons." (2014) 13:3 Journal of HIV/AIDS \& Social Services 306-323.

53 W W Darrow et al, "The gay report on sexually transmitted diseases." (1981) 71:9 Am J Public Health 1004-1011.

54 Anthony J Langlois et al, "Community, identity, orientation: sexuality, gender and rights in ASEAN" (2017) 30:5 The Pacific Review 710-728.

55 Gadis Arivia \& Abby Gina Boangmanalu, "When the State is Absent: A Study of LGBT Community in Jakarta” (2015) 4:1 Indonesian Feminist Journal 4-12.

56 Ibid. 
injustices endured by the LGBT community are not easily noticed and attempts to advocate for rights or protections are deemed "not urgent." 57 This is often the reason families, community and religious leaders and policymakers fail to see LGBT people as humans with rights, including equality with other groups. ${ }^{58}$

Misconceptions and other widely held beliefs about LGBT people manifest through incidences of violence against the Indonesian LGBT community. ${ }^{59}$ LGBTrelated violence worsened with escalating religious conservatism. ${ }^{60}$ Even though Indonesia is not a religious state, religion plays a very important role in determining societal norms. By law, Indonesia acknowledges five religions, Islam being the most popular. In Islamic teaching, homosexuality is categorized as a $\sin .{ }^{61}$ There is no specific law identifying or protecting LGBT rights at the national level; the closest extant legislation is a marriage law that permits marriages and divorces between people of the same religion, with none of the acknowledged religions allowing same-sex marriages. Cases in which LGBT-related prosecutions have taken place in reference to the Penal Code (KUHP) fall under the crime of molestation, regulated by Article 292 of the KUHP, the same regulation is utilized to punish sexual abuse of children. Exploiting the momentum geared toward amending the Code, LGBT opponents are proposing an expansion of the Code criminalizing adult homosexuality, with a nine-year maximum jail penalty. ${ }^{62}$

In the Philippines, rejection exists in the form of discrimination, religious intolerance, ${ }^{63}$ and debates over same-sex marriage versus civil unions. ${ }^{64}$ Public support for same-sex marriage is one of the primary hurdles to integrating LGBT people into Philippine society. Cases of abuse, discrimination and deaths totaling 141 people since

$1996^{65}$ exemplify intolerance in the country. Reports indicate that assault and murder cases (both successful and attempted), the lack of comprehensive national mechanisms to monitor instances of discrimination, prejudice, bias and violence, gay-related hostility at home and in the workplace and hate crimes are all related to the differences in gender

57 Ibid.

58 Ibid.

59 N Masli, "Being LGBT in Indonesia, Why Attacks on the Community are Growing”, (2018), online: Lifegate 〈https://www.lifegate.com/people/news/lgbt-in-indonesia-attacks-increasing>.

60 Ibid.

61 Ibid.

62 Ibid.

63 Rapplercom, "How Religious Groups Clashed over LGBTQ+ Rights at Pride 2019”, (2019), online: <https://www.rappler.com/move-ph/234350-how-religious-groups-clashed-lgbtq-rights-pride-march2019>.

64 RA Gita, "SWS: 61\% of Filipinos Reject Same-Sex Marriage", (2018), online: Sunstar.com <https://www.sunstar.com.ph/article/1750492>.

65 Rainbow Rights Project \& Philippine LGBT Hate Crime Watc, The Status Of Lesbian, Gay, Bisexual And Transgender Rights In The Philippines: Submission to the Human Rights Council for Universal Periodic Review 13th Session (Universal Periodic Review, 2012). 
and sexual orientation. ${ }^{66}$ Such cases are shown to lack methodologies allowing government security forces to determine the relationship and existence of hate, prejudice or bias to the crime committed. ${ }^{67}$ LGBT rights defenders in Muslim areas of the Philippines are pressured to be less open with their activities due to religious radicalization, ${ }^{68}$ with instances of religious leaders and lay members becoming aggressive enough to issue messages of death and disease towards LGBT people. ${ }^{69}$

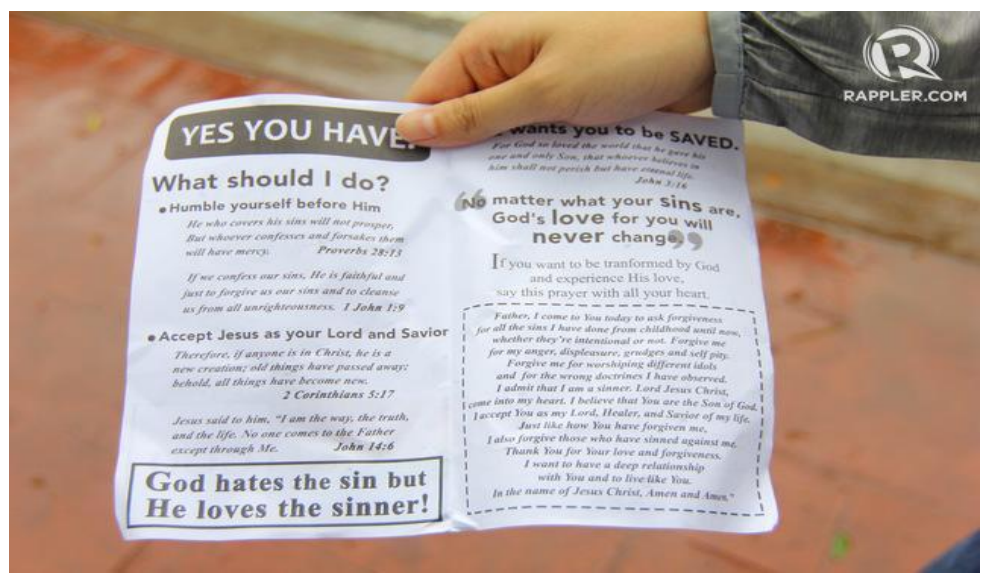

Figure 1: Pamphlets with religious messages issued by protesters during Manila Pride 2019. ${ }^{70}$

\section{Tolerance}

Beyond rejection, the growing awareness, opennes and acceptance towards LGBT communities exhibits a range of tolerance for the minority. Legislative support, ${ }^{71}$ civil movements ${ }^{72}$ and advocacy ${ }^{73}$ persist in the Philippines, whilst Indonesia, once known for taking a friendly stance towards the LGBT community is slowly moving in the opposite direction , citing the country is "...not banning gay people...but [is] trying to give them

66 Ibid.

67 Ibid.

68 Ibid.

69 Ibid.

70 Rappler.com, supra note 63.

71 MJB Deslate, "The SOGIE Equality Bill", (2016), online: Divina Law Dynamic Lawyering $<$ https://divinalaw.com/sogie-equality-bill/>.

72 B Magsambol, "Record Breaking: 70,000 Filipinos join Metro Manila Pride 2019”, (2019), online: <https:/www.rappler.com/move-ph/234225-metro-manila-pride-2019-attendees-breaks-record>.

73 M Waters, "The First Pride Marches in Photos" SmithsonianCom (2019), online: <https://www.smithsonianmag.com/history/first-pride-marches-photos-1180972379/?utm_source=facebook.com\&utm_medium=socialmedia\&fbclid=IwAR3uf1puFi6KrCf BqKil6Qwo__pfxvVW0VqawQJiD5CTNk91pvZzmGvci4Q>. 
freedom within certain limits." ${ }^{74}$ Despite the majority of Indonesian people negatively perceiving the LGBT community, many believe its members deserve to live in the country. ${ }^{75}$ A survey revealed 87.6 percent out of 1,200 respondents consider the LGBT community a threat, whilst 81.5 percent believe it is prohibited by religion. However, 57.5 percent of the respondents said members of LGBT community have the right to live as citizens. ${ }^{76}$ Nearly 50 percent of those who believe the LGBT group are a threat indicated that they would still accept family members whose primary sexual orientation was toward people of the same gender. The survey found 45.9 percent of respondents would still consider LGBT relatives part of their family, while the remaining 53.5 percent said they would not. ${ }^{77}$ Director Ade Armando of Saiful Mujani Research and Consulting (SMRC) considers the survey good news for those who believe in democracy and human rights. ${ }^{78}$ Although the majority said homosexuality is prohibited, they believe LGBT community members may live in Indonesia, thereby exhibiting a level of tolerance.

Cases of tolerating the existence, presence and most, if not all, of the activities of homosexual individuals and groups are present, yet overshadowed by the limitations set towards their primary advocacy points, such as the legalization of same-sex marriage. One of the larger issues for homosexual minorities, acceptance levels, is highlighted in the diagram below:

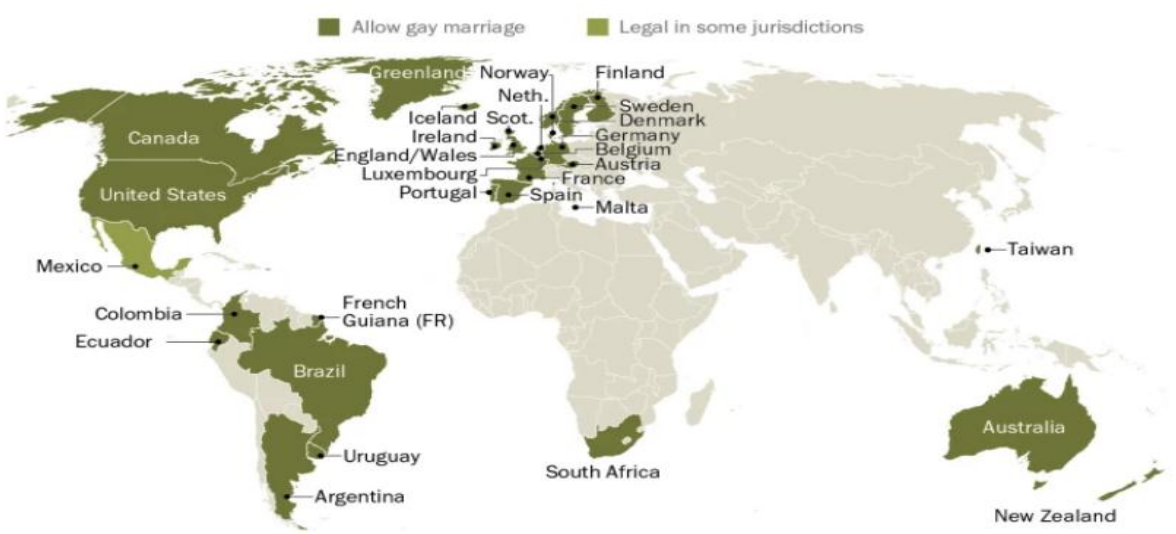

Figure 2: State of Gay Marriage around the World as of June 2019.79

74 V Bevins, "Once-Tolerant Indonesia Moves to Outlaw Gay and Extramarital Sex", The Washington Post (2018), online: <https:/www.washingtonpost.com/world/asia_pacific/once-tolerant-indonesiamoves-to-outlaw-gay--and-extramarital--sex/2018/02/09/d82b7112-0b79-11e8-998c-

96deb18cca19_story.html>.

75 Marguerite Afra Sapiie, "LGBT people viewed negatively, but accepted as Indonesian citizens", The Jakarta Post (25 January 2018), online: <https://www.thejakartapost.com/news/2018/01/25/lgbtfollowers-viewed-negatively-but-accepted-as-indonesian-citizens.html>.

76 Ibid.

77 Ibid.

78 Ibid.

79 David Masci \& D Desilver, “Gay Marriage Around the World” Pew Research Center.”, (2019), online: <https://www.pewresearch.org/fact-tank/2019/06/21/global-snapshot-same-sex-marriage/>. 
As shown above, areas that have legalized gay marriage are predominantly located in Western countries. ${ }^{80}$ As for Southeast Asia, there is yet to be a conclusive response. Indonesia and the Philippines have yet to issue otherwise. This distribution of marriage legalization shows that despite tolerating gayness, there are countries that abhor same-sex unions. Contrastingly, on smaller scale issues, gay people are free to practice and enjoy basic civil and human rights.

In the Philippines, gay people enjoy the right and freedom to express and form associations and groups. This and other various components form a stark contrast to Indonesia's penalization of gay activities and practices. The state of gay freedom in the Philippines exists despite the aforementioned report highlighting abuse, discrimination, bias and hate towards the minority. ${ }^{81}$ Still, some claim that the tolerance received by LGBT Filipinos is dependent upon stereotyping, ${ }^{82}$ for example, assumptions that Filipino gay men are "effeminate," "cross-dressing men " or "squealing with impunity" 83 branding Filipino gay men as humorous ${ }^{84}$ individuals that are distant from rights commonly associated with citizens. This treatment is a far cry from social acceptance that all human beings ought to be accorded.

\section{GAY COMMUNITY IN INDONESIA}

The LGBT community can be described as a minority group, i.e., a social group characterized by relative powerlessness in their interest-representing abilities. ${ }^{85}$ Gays and lesbians suffer from heterosexism ${ }^{86}$ along with homophobia which is the cultural devaluation of homosexuality. Their sexuality is disparaged, LGBT individuals are subject to shaming, harassment, discrimination and violence whilst simultaneously being denied legal rights and equal protection, all of which fundamentally constitute a denial of recognition. Furthermore, the LGBT minority suffers serious economic injustices; on the basis of sexuality individuals can be summarily dismissed from paid work and denied family-based social-welfare benefits. However, far from being rooted directly in economic structures, such discrimination derives instead from an unjust cultural valuation structure. Even though Indonesia has a secular constitution and homosexuality is not criminalized, a recent poll shows that 93 percent of Indonesians feel homosexual

80 Ibid.

81 Rainbow Rights Project \& Philippine LGBT Hate Crime Watc, supra note 65.

82 UNDP \& USAID, supra note 49.

83 Ibid.

84 Ibid.

85 Social Exclusion of Lesbian, Gay, Bisexual and Transgender (LGBT) People in Hungary, Research Report, by Mocsonaki Tákacs \& Tamás P Tóth, Research Report (Institute of Sociology, Hungarian Academy of Science, 2008).

86 Nancy Fraser, Justice Interruptus: Critical Reflections on the "postsocialist" Condition (New York \& London: Routledge, 1997). 
couples should not be accepted.$^{87}$ Soeharto's authoritarian New Order regime had more resources to impose its agenda to a greater degree than the Sukarno's Old Regime. ${ }^{88}$ Since the New Order regime fell in 1998, Indonesia has been a society under enormous political stress and change. Its fledgling democratic government faced increasingly Islamicized pressure in terms of governance and law. In the post-September 11 climate, the rise of militant Islamic groups and extreme forms of atavistic behavior across Indonesia has led to endemic and pervasive violence targeted at both ethnic minorities and identified homosexuals, who are often perceived as deviant or corrupted by Western values. Groups that have explicitly targeted the LGBT community have included the Indonesian Council of Ulemas, Indonesia's top Muslim clerical body, the Islamic Defender Front, an extremist group known for its violent tactics and the Hizbut-Tahrir Indonesia. ${ }^{89}$

The presence of homosexuality in Indonesian society is considered a deviation from social norms a situation that has been influenced by the 'creeping' Islamization and its widespread impact on the perception of what is considered normal and appropriate moral behavior. At the beginning of the 1980s, homosexuality became closely connected to the spread of HIV/AIDS in the minds of many Indonesians. As a consequence in Indonesia people call gay people orang sakit ('the sick') and they are targeted via social exclusion, violence and other forms of physical, psychological and emotional persecution. ${ }^{90}$ The founder of Arus Pelangi or Rainbow Flow, a non-profit organization for LGBT persons, King Oey notes: "Discrimination occurs everywhere. If someone is known to be homosexual, taunts and gossip will follow, as well as harassment and loss of employment." Such sentiment serves to exacerbate the widespread stigma that homosexuality is a disease.

In some elements of daily life, homosexuality has been informally welcomed, meaning that LGBT individuals can be accepted so long as they do not cause trouble in society ${ }^{91}$ However, in reality, discrimination against the LGBT community remains both very common and often unresolved. Therefore, to avoid social discrimination many of Indonesia's gays play a form of 'hide and seek.' They tend to see themselves as open (terbuka) in certain spaces for example, in cruising spaces and in the homes of friends and closeted (tertutup) in others such as the workplace or the family home. ${ }^{92}$

87 Alexandra Demetrianova, "The Invisible LGBT in ASEAN: Part 2", (2014), online: Simply $S_{y x}$ <http://simplysxy.com/articles/2014/07/05/the-invisible-lgbt-people-in-asean-part-2/>.

88 Tom Boellstorff, The Gay Archipelago: Sexuality and Nation in Indonesia (Princeton University Press, 2005).

89 Baden Offord, "Singapore, Indonesia and Malaysia: Arrested Development!" in Manon Tremblay, David Paternotte \& Carol Johnson, eds, The Lesbian and Gay Movement and the State Comparative Insights into a Transformed Relationship (Ashgate, UK: Routledge, 2011).

90) Ibid.

91 Rizki Theodorus Johan, "Discovering the 'Others': Unearthing Homosexual Identity Construction in Selected Indonesia Contemporary Novels and Short Stories" (2011) Proceedings The Asian Conference on Literature and Librarianship.

92 Boellstorff, supra note 88. 


\section{GAY COMMUNITY IN THE PHILIPPINES}

The community of homosexual men, termed "bakla" or "beki" in the Philippines, is treated quite well relative to other countries. A survey conducted by the Pew Research Center in 2013 indicates a prominent tolerance and acceptance for the homosexual community in the Philippines..$^{93}$ Various dimensions such as religion and politics play key roles in this kind of treatment. The level of awareness regarding homosexuality is parallel to the tolerance levels for the group.

The gay community in the Philippines currently enjoys a relatively better standing compared to its Southeast Asian counterparts. Openness towards homosexual men is manifested through support for gay-related activities such as gay pride parades, ${ }^{94}$ seeing multitudes ${ }^{95}$ of supporters ranging from celebrities ${ }^{96}$ to gay-rights activists and advocates. ${ }^{97}$ This movement aims to generate the necessary traction to gain acceptance into mainstream society. Apart from pride parades, advocacy to gain legislative support for the gay community is apparent with the approval of House Bill No. 4982 or Act Prohibiting Discrimination on the Basis of Sexual Orientation or Gender Identity or Expression (SOGIE) and Providing Penalties. Therefore, an anti-discrimination Bill was seeking to fulfill the provisions stated in the Equal Protection Clause of the 1987 Philippine Constitution ${ }^{98}$ in Congress. ${ }^{99}$ The Bill, however, failed to pass the Senate, ${ }^{100}$ forcing earmarked legislation for the benefit of the LGBT community to come to a standstill, including all corresponding provisions and penalties. Despite the active advocacy movement, the country seems to be divided where full support for the LGBT community is concerned. ${ }^{101}$

93 Philip C Tubeza, "PH ranks among most gay-friendly in the world", online: InquirerNet <https://globalnation.inquirer.net/76977/ph-ranks-among-most-gay-friendly-in-the-world>.

$94 \quad$ Waters, supra note 73.

95 Magsambol, supra note 72.

96 Rapplercom, "Look: Stars, Beauty Queens at Metro Manila Pride 2019", (2019), online: <https://www.rappler.com/entertainment/news/234238-photos-celebrities-beauty-queens-manilapride-2019>.

97 AFP, "Thousands March for Equality in Manila's Pride Parade", (2019), online: Philippine Star $<$ https://www.philstar.com/headlines/2019/06/30/1930782/thousands-march-equality-manilas-prideparade>.

98 Deslate, supra note 71.

99 Republic of the Philippines, "House Bill No. 4982: An Act Prohibiting Discrimination on the Basis of Sexual Orientation or Gender Identity or Expression (SOGIE) and Providing Penalties Therefore”, online: <http://www.congress.gov.ph/legisdocs/first_17/CR00101.pdf>, Quezon City, Philippines.

100 Ibid.

101 GM Ablon, "Passage of SOGIE Bill Urged", online: Rappler <https://tribune.net.ph/index.php/2019/07/01/passage-of-sogie-bill-urged>. 
Due to the lack of national legislation protecting LGBT people from discrimination, ${ }^{102}$ a number of Local Government Units (LGUs) have enacted antidiscrimination ordinances encompassing gender identity, sexual orientation and expression in their declared protected categories. ${ }^{103}$ Such localities include:

\begin{tabular}{|c|c|}
\hline Region & City/Province \\
\hline $\begin{array}{c}\text { Cordillera Administrative Region } \\
\text { (CAR) }\end{array}$ & Baguio City \\
\hline National Capital Region (NCR) & Quezon City \\
\hline \multirow[t]{3}{*}{ Region I } & Candon City \\
\hline & Dagupan City \\
\hline & Vigan City \\
\hline Region III & Angeles City \\
\hline \multirow[t]{3}{*}{ Region IV - A } & Antipolo City \\
\hline & Batangas Province \\
\hline & Cavite Province \\
\hline Region IV - B & Puerto Princesa City \\
\hline \multirow[t]{2}{*}{ Region VI } & Bacolod City \\
\hline & Iloilo Province \\
\hline \multirow[t]{2}{*}{ Region VII } & Cebu City \\
\hline & Mandaue City \\
\hline Region VIII & Municipality of San Julian \\
\hline Region XI & Davao City \\
\hline Region XII & General Santos City \\
\hline
\end{tabular}

102 Xavier Javines Bilon \& C De Leon, "With no national law, can we rely on local ordinances to protect LGBTQs against discrimination?”, (2018), online: cnn <https:/cnnphilippines.com/life/culture/2018/06/25/antidiscrimination-bill-lgbtq.html>.

103 Eric Julian Manalastas, “Anti-Discrimination Ordinances” (2015) Department of Psychology, University of the Philippines, online: <https://pages.upd.edu.ph/ejmanalastas/policies-ordinances>. 


\begin{tabular}{|c|c|}
\hline Region XIII & Butuan City \\
& Agusan del Norte Province \\
& Dinagat Islands Province \\
\hline
\end{tabular}

Table 1: Cities and Provinces with Anti-Discrimination Ordinances for LGBT. Adapted from Manalastas, 2015.104

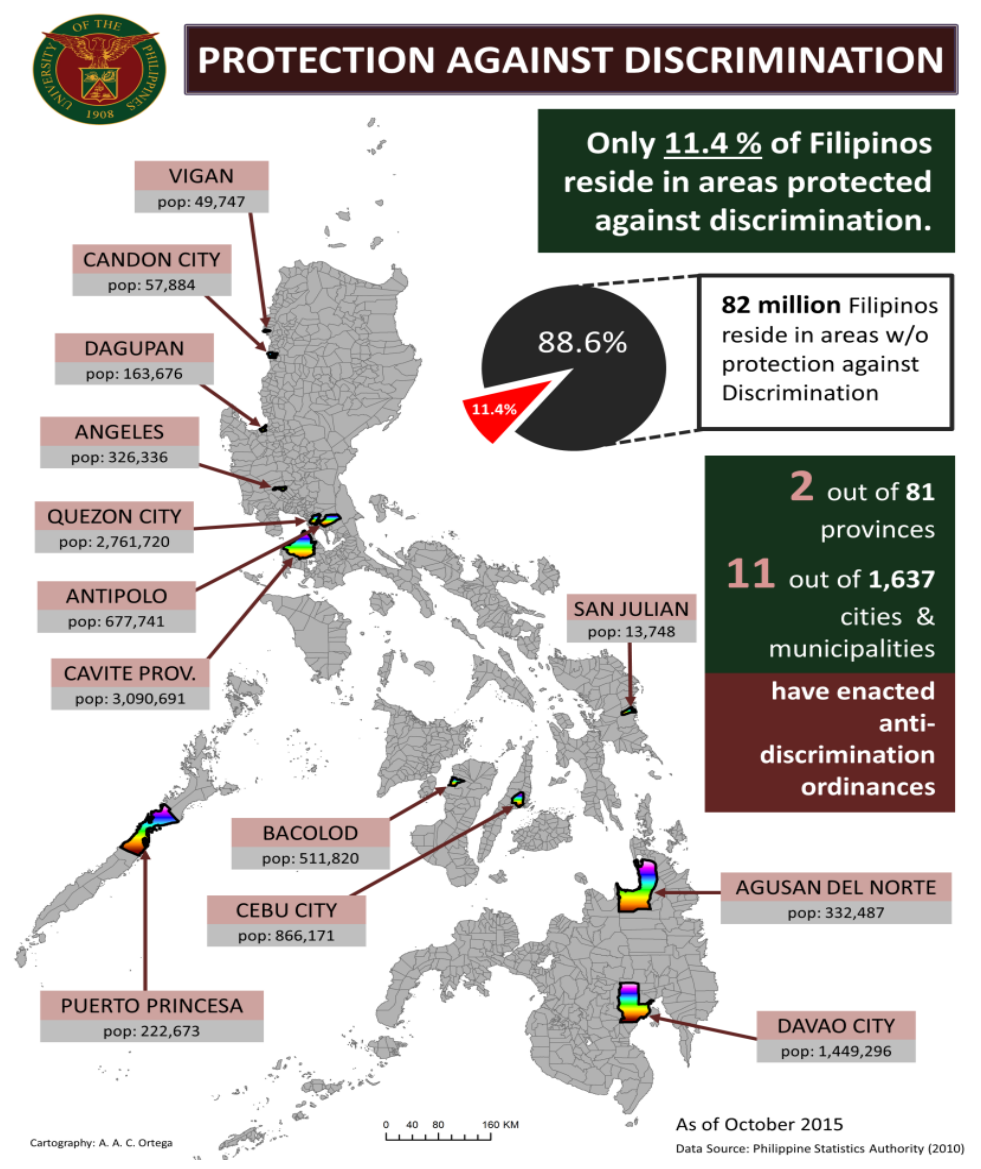

Figure 3: Cities and Provinces with Anti-Discrimination Ordinances for LGBT. ${ }^{105}$

104 Ibid.

105 Ibid. 
The number of areas with anti-discriminatory ordinances continues to grow as more and more cities push for the passing of the SOGIE Bill. ${ }^{106}$ The active support of the LGUs for the LGBT community through these ordinances ${ }^{107}$ has been lauded. ${ }^{108}$ It illustrates how the gay-rights movement in the country is becoming increasingly progressive.

However, despite being tolerated in the country, homosexuality and LGBT community members fail to uphold the necessary components for total acceptance. ${ }^{109}$ Sentiments such as "it's okay that you are gay as long as you're not working in my company" persist, ${ }^{110}$ restricting the participation and acceptance of gay people in mainstream society. In terms of social classification the gay community are considered second or third class citizens. ${ }^{111}$ Such mistreatment along with stereotyping and violence, ultimately debilitates the capacity of gay people as well as other members of the LGBT community toward social acceptance.

\section{GAYNESS AND CULTURE}

\section{Indonesian Gay Culture}

Islam is a complete blueprint for life for Muslims, requiring believers to follow its template. ${ }^{112}$ Islam prohibits sexual intercourse amongst same-sex relationships. ${ }^{113}$ This prohibition is legally justified based on the fact that these relationships operate outside of the marriage contract, making them illegal according to Islamic law. ${ }^{114}$

However, studies have also shown that Indonesia is home to a number of 'sacred' or 'traditional' forms of homosexuality, the most well-known being the bissu of South

106 A Rivera, “Marikina Ordinance Upholds LGBT Community Equal Right” (2019) People’s Journal, online: <https://journal.com.ph/news/metro/marikina-ordinance-upholds-lgbt-community-equalrights>.

107 chase, “Anti-Discrimination Ordinances Across the Philippines”, (15 May 2017), online: Transgender Philippines <http://www.transph.org/information/philippine-anti-discrimination-ordinances/>.

108 S Crisostomo, "LGUs lauded for measures on LGBT rights", (2019), online: Philippine Star <https://www.philstar.com/headlines/2019/06/25/1929308/lgus-lauded-measures-lgbt-rights>.

109 N Guitierrez, "LGBTQ Activists: We are Tolerated but not Accepted in the Philippines", (2017), online: Rappler <https:/www.rappler.com/nation/170091-lgbtq-rights-philippines-tolerated-notaccepted>.

110 Ibid.

111 Guitierrez, supra note 109.

112 S Habib, Islam and Homosexuality (Santa Barbara, California: ABC-CLIO, LLC, 2010).

113 M Alipour, "Shī'a neo-traditionalist scholars and theology of homosexuality: review and reflections on Mohsen Kadivar's shifting approach" (2018) 24:3 Theology \& Sexuality 200-218.

114 Jeffrey S Siker, Homosexuality and Religion: An Encyclopedia (Westport, Conn: Greenwood Press, 2006). 
Sulawesi and the warok of the Ponorogo region of East Java. ${ }^{115}$ The bissu are described as androgynous shamans who symbolically embody both male and female elements. ${ }^{116}$ The Bugis of South Sulawesi-i.e., the society in which the bissu are found-acknowledge four possible genders, as well as a fifth 'para-gender' identity. In addition to male-men (oroane) and female-women (makunrat), there are calalai, biological females who take on many of the roles and functions expected of men; calabai, biological males who adhere to the expectations of women in many respects and bissu. ${ }^{117}$ Meanwhile, a warok is a leader of the Reyog dance. In this tradition, the warok engages in homoerotic relations with a younger man, known as gemblak, as heterosexual intercourse with women is understood as polluting. ${ }^{118}$ The gemblak is normally chosen for his poise and physical appearance, typically characterized as androgynous and light in facial complexion; the latter is sometimes enhanced with facial powder. ${ }^{119}$ During performances, the gemblak sometimes dresses in feminine attires, particularly the kebaya (blouse), jarik batik (wrap-around skirt), and sampur or selendang (scarf). ${ }^{120}$

Currently, Indonesian gay men lead very different lifestyles. For instance Indonesian gay life in Jakarta, the capital city of Indonesia and the largest metropolitan area in Southeast Asia, ${ }^{121}$ located in the north-west of Java near the side of the Java Sea, with a population of 10.486 million in 2016. ${ }^{122}$ Despite general rejection from the country, gay communities continue to live and thrive in the city. Gay culture, centralized on sexual tendencies, is apparently being practiced. Gay bars ${ }^{123}$ and gay saunas ${ }^{124}$ filled with necessary amenities exist. Websites ${ }^{125}$ that support gay-related activities, events, groups and communities are also a part of gay life in Jakarta.

115 Ben Murtagh, Genders and Sexualities in Indonesian Cinema. Construction of gay, lesbi and waria identities on screen (New York: Routledge, 2013).

116 Sharyn Davies, "Gender diversity in Indonesia: Sexuality, Islam and queer selves" (2010) Gender Diversity in Indonesia: Sexuality, Islam and Queer Selves 1-257.

117 Ibid.

118 Ian Douglas Wilson, "ReogPonorogo: Spirituality, Sexuality and Power in a Javanese Performance Tradition" (1999) 2 Intersections: Gender and Sexuality in Asia and the Pacific, online: <http://intersections.anu.edu.au/issue2/Warok.html>.

119 Ibid.

120 Margaret Kartomi, "Performance, Music and Meaning of ReyogPonorogo" Indonesia (1976).

121 D Rukmana, "The Megacity of Jakarta: Problems, Challenges and Planning Efforts", (2014), online: Indonesia's Urban Studies <http://indonesiaurbanstudies.blogspot.com/2014/03/the-megacity-ofjakarta-problems.html>.

122 The World's Cities in 2016, by United Nations (2016).

123 http://www.apolloclub-jakarta.com

124 http://www.atlantis-jakarta.com/

125 https://www.travelgayasia.com/ 


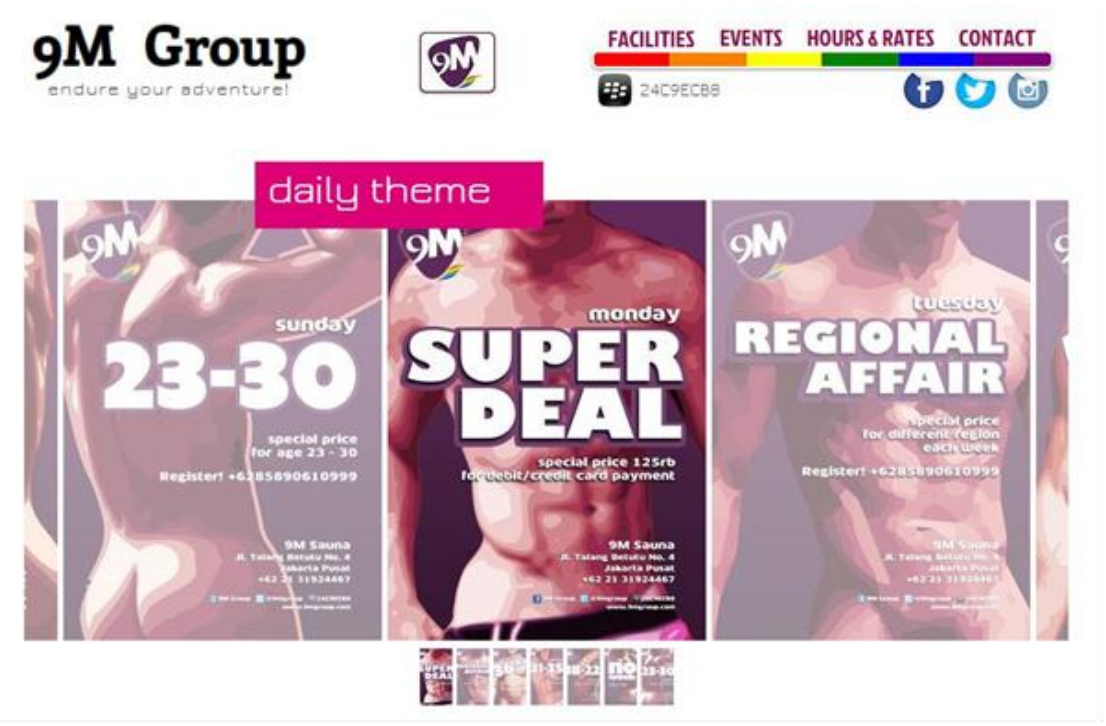

Figure $4:$ A website supporting gay-related sexual events ${ }^{126}$

These establishments have become a hub for gay activities, such as "go-go-boys," drag shows and others which mainly target audiences seeking sexual activity and indulgence.
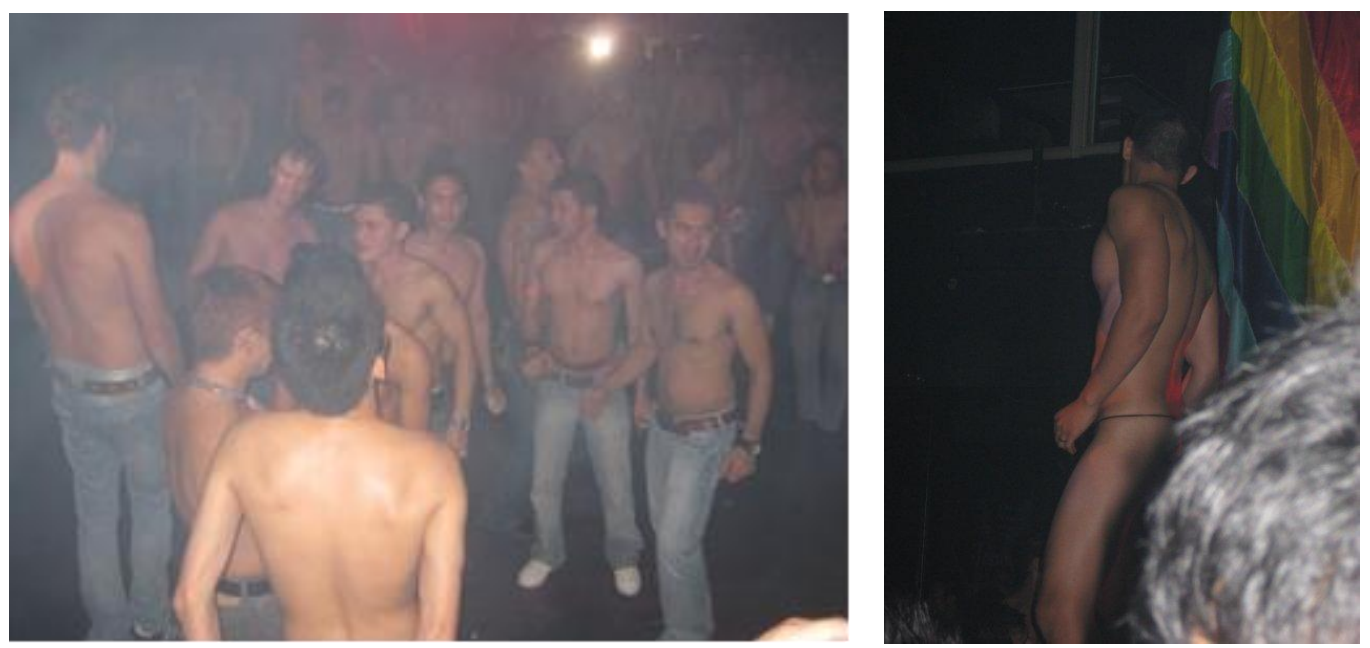

Figures $5 \& 6:$ Gay-related events (shows) in gay bars. ${ }^{127}$

The emergence of gay venues in Jakarta demonstrates the city's gay friendliness. ${ }^{128}$ The development of gay bars and gay saunas in Jakarta runs contrary to the dictums of Islam, resulting in a violent clash of cultures. Rampant abuse and intolerance ${ }^{129}$ persist, leading most Indonesian gay men to hide their identities in fear of possible prosecution

126 http://www.9mgroup.com/\#!9m/c158s

127 http://www.jakarta100bars.com/2010/12/nirvana-gay-jakarta.html

128 Marcus, supra note 41.

129 S Widianto, "LGBT Jakartans: Worse than a Nuclear Bomb. We Just Want to be Accepted", (2016), online:

<https://www.theguardian.com/cities/2016/nov/26/lgbt-young-jakartans-nuclear-bombaccepted>. 
amidst suggestions of imposing pre-marital sex bans. ${ }^{130}$ Gay culture in Indonesia and gay people also face a tirade of misconceptions, such as gayness being a "mental disorder"131 and anti-LGBT sentiments in Indonesian political circles. ${ }^{132}$ LGBT communities have also been considered a moral threat. ${ }^{133}$

\section{Philippine Gay Culture}

Historically, accounts of gay men in the Philippines date back to the Pre-Colonial ${ }^{134}$ period. Early accounts of Spanish conquistadores describe some of the cultural practices of cross-dressing and transvestitism in the form of the babaylan, a local spiritual leader likened to a priestess or shaman and are mostly female. ${ }^{135}$ However, some male members of early Philippine communities wore female clothing and pretended to be women in order to perform the duties of the babaylan. ${ }^{136}$ This function extended beyond pretension and became socially accepted as true, so much so that some became "married" to other men and engaged in sexual activities. ${ }^{137}$ Such deep connections can also be traced in the Filipino language, ${ }^{138}$ with terms, such as syoki (believed to mean "with weak spirit"), pertaining to the inherently weak personality or constitution of gay men. Another term, bakla, refers to cross-dressing gay men. ${ }^{139}$ These terms are used to denote that gayness is the act of a male taking on female mannerisms, habits and personalities. ${ }^{140}$

Despite living in a country labeled "gay friendly," ${ }^{141}$ members of the gay community experience bullying, discrimination, lack of access to LGBT related information and

130 J Emont, “Indonesia’s Top Court Weighs Ban on Sex Outside Marriage”, Washington Post (2016), online: <https://www.washingtonpost.com/world/asia_pacific/sex-is-about-to-get-much-morecomplicated-in-indonesia/2016/10/25/e12db900-8f15-11 e6-a6a3d50061aa9fae_story.html?utm_term=.6d3735229a1e>.

131 L Yosephine, "Indonesian psychiatrists label LGBT as mental disorders", The Jakarta Post (2016), online: <https:/www.thejakartapost.com/news/2016/02/24/indonesian-psychiatrists-label-lgbtmental-disorders.html>.

132 NF Ramadhani \& I Parlina, “Anti-LGBT Rhetoric to Spike Ahead of Elections”, The Jakarta Post (2016), online: <https://www.thejakartapost.com/news/2016/08/12/anti-lgbt-rhetoric-spike-aheadelections.htm>.

133 E Merigo, "In Indonesia, LGBT Communities Viewed as a Moral Threat - Condemned by Religion and, increasingly, by Law" South China Morning Post (7 April 2019), online: <https:/www.scmp.com/magazines/post-magazine/long-reads/article/3004634/indonesia-lgbtcommunity-viewed-moral-threat $>$.

134 Presidential Museum and Library, "Pre-Colonial Manila", online: Malacanang Palace <http:/ /malacanang.gov.ph/75832-pre-colonial-manila/>.

135 UNDP \& USAID, supra note 49.

136 Ibid.

137 Ibid.

138 Ibid.

139 Ibid.

140 Ibid.

141 Tubeza, supra note 93. 
assault from as early as childhood. ${ }^{142}$ Even with recognition that gayness is neither a pathological disorder nor a different type of human development, such experiences and cases prevail. ${ }^{143}$ The country may show support to gay men similar to any individual's rights $^{144}$ such as right to association, right to self-identity, and so on, but there is still discrimination anchored in cultural and religious views. It is common for a typical Filipino family to despise gayness. As a patriarchal society, Philippine culture demands and appreciates manliness. Men who exhibit characteristics associated with gayness are often taunted with words such as "bakla ka ba?" (are you gay?) and "bakla ka pala eh!" (so you are gay!). Being a majority Christian country also creates tension, as devout followers of the religion openly reject gay people due to their "abnormality and immorality." ${ }^{45}$ Discriminatory acts permeate schools, workplaces, business establishments and other places. ${ }^{146}$

Accounts of gay people experiencing discrimination during World War II, in their role as "comfort gays" ${ }^{147}$ or homosexual prostitutes confirms the length of their presence and profound impact on Philippine culture and history. Even after the war, gay people continued to exist in neighborhood organizations that provided entertainment, conducted beauty pageants, in fashion and entertainment. ${ }^{148}$ In the early years of Philippine cinema, gayness was portrayed in numerous films, often through personalities and traits associated with gay people of that period. Usually through humor and comical acts, such depictions allowed the gay community to slowly gain recognition and partial acceptance in society. However, it also depicted gay people as sexually predatory, increasing stigmatization, ${ }^{149}$ despite research failing to show the correlation between homosexuality and known molestations. ${ }^{150}$ The prevalence of gay related writings, ${ }^{151}$ and the change in relationship types from gay men-heterosexual men to gay-gay relationships in the succeeding years proved how this minority further permeated Philippine culture

142 Just Let Us Be: Discrimination against LGBT Students in the Philippines, by R Thoreson \& D Lee (USA: Human Rights Watch, 2017).

143 Psychological Association of the Philippines, Reaffirmation of Non-Discrimination of LGBT Filipinos (2013).

144 The 1987 Constitution of the Republic of the Philippines. Art. III. Bill of Rights., 1987.

145 Alfred C Kinsey, Wardell R Pomeroy \& Clyde E Martin Sexual, "Sexual Behavior in the Human Male" (2003) 93:6 American Journal of Public Health 5.

146 Eric Julian Manalastas \& Beatriz Torre, "Social Psychological Aspects of Advocating LGBT Human Rights in the Philippines" University of the Philippines, online: <https://pages.upd.edu.ph/sites/default/files/ejmanalastas/files/manalastas_torre_fil_lgbt_activism.pd f>.

147 R Klein, "Markova: Wartime Comfort Gay in the Philippines. Interview with Walter Dempster Jr" (2006) Intersections, online: <http://intersections.anu.edu.au/issue13/klein_interview.html>.

148 UNDP \& USAID, supra note 49.

149 Ibid.

150 Gregory M Herek, "Facts About Homosexuality and Child Molestation", (2018), online: UC Davis <https://psychology.ucdavis.edu/rainbow/html/facts_molestation.html>.

151 UNDP \& USAID, supra note 49. 
in the 1980s. ${ }^{152}$ By 1990, the country experienced rapid leaps in gay awareness marking the year as the emergence of the Philippine LGBT movement. ${ }^{153}$ This progressed further as is evidenced by the participation of Pride March in 1994, with the Philippines gaining distinction as the first country to host a Pride Parade in Asia and the Pacific. ${ }^{154}$ Filipino gays also enjoy a fairly free lifestyle in the Philippines. Bars and similar establishments specializing in gay customers are found across the country. ${ }^{155}$ Some of these establishments openly declare the safety and welfare of their employees and show their open support for the gay community. ${ }^{156}$

Furthermore, the emergence of multiple social components such as advocacy and support organizations attest the Filipino people are very tolerant of gay people and their presence. Filipino gays freely made and used a unique dialect that mixed Tagalog (Philippine national language), English, Spanish, celebrity names and trademark brands. ${ }^{157}$ This language is commonly known as swardspeak/gayspeak/baklese ${ }^{158}$ currently known as "gay lingo". This was done to avoid discrimination, embarrassment and outright identification of their gender preference. ${ }^{159}$ It was made during the outbreak of the Western HIV epidemic, which added to negative views towards gay men leaving them ${ }^{160}$ prone to an increase in cases of abuse and discrimination. Philippine NGOs attempted to responded to these issues but rather then help, they exacerbated public fear and views towards gay people.

The detrimental experiences of Filipino gay men across the archipelago highlight general notions of sexual orientation and gender identity (SOGI), bringing forth lobby groups or those seeking legislative approval and support in various contexts such as sexual health, acceptance, rights groups, and so forth; but remains loose due to disaggregation and existence of subcultures within the minority. The absence of a unified, monolithic gay culture ${ }^{161}$ inhibits the minority's capacity to create a solid movement that will potentially lay the groundwork for pro-social acceptance.

152 ML Tan, "Survival through pluralism: emerging gay communities in the Philippines." (2001) 40:3-4 Journal of Homosexuality 117-142.

153 UNDP \& USAID, supra note 49.

154 Ibid.

155 S Bhandari, "The Best LGBTQ Bars and Clubs in Manila, Philippines”, (2018), online: Culture Trip <https://theculturetrip.com/asia/philippines/articles/the-best-lgbtq-bars-and-clubs-in-manilaphilippines/>.

156 690 Manila, “The One 690 Entertainment Bar”, online: <http://www.690manila.com>.

157 G Ricordeau, "Review: Philippine Gay Culture: Binabae to Bakla, Silahis to MSM" (2009) 19 Intersections: Gender and Sexuality in Asia and the Pacific, online: <http://intersections.anu.edu.au/issue19/ricordeau_review.htm>.

158 Ibid.

159 GR Pascual, "Sward Speak (Gay Lingo) in The Philippine Context: A Morphological Analysis" (2016) International Journal of Advanced Research in Management and Social Sciences, online: <http://www.garph.co.uk/IJARMSS/Dec2016/4.pdf>.

160 UNDP \& USAID, supra note 49.

161 Ibid. 


\section{GAYNESS AND RELIGION}

Islam as a religion incorporates ritual practices and guidelines for a complete way of life and is reflected in Muslim cultural beliefs and practices. Islam defines culture and culture gives meaning to every aspect of an individual's life. ${ }^{162}$ Islam views marriage as sacred and family as the foundation of society, which provides stability and security to individuals and families. Men are seen as the protectors of women and play an important role in decision making. ${ }^{163}$ Homosexuality is condemned and considered sinful and punishable by Allah. Whilst Muslim couples are encouraged to have children, sex outside of marriage is discouraged and contraception and family planning are merely allowed. ${ }^{164}$ In addition, the Islamic faith emphasizes many strict rules involving most components of life including cleanliness, death and food consumption. ${ }^{165}$ Such strict religious practices and beliefs inhibit the acceptance of homosexual men into the mainstream society. Condemnation of simply being gay prevails, a fact that is currently growing deeper and harsher in the religious circles of Indonesia.

Additionally, the Catholic Church in the Philippines has repeatedly expressed its lack of support for the gay community. This is in line with Catholic perceptions of the sacredness of family ${ }^{166}$ and its position as the basic social unit of society. This view connotes the incapacity of homosexual people to procreate, which is particularly evident in the move to legalize same sex unions. ${ }^{167}$ Surveys have reflected that only two out of ten people favor the notion ${ }^{168}$ and despite not interfering with their basic rights, most Filipinos (61 percent) ${ }^{169}$ are yet to accept ${ }^{170}$ the "radical” social changes that homosexual people seek. Though the passage of the SOGIE Bill ${ }^{171}$ encountered hurdles ${ }^{172}$ due to conservative politicians ${ }^{173}$ who did not share the same point of view in terms of same-sex civil unions occurring in the largely Christian country.

162 Ibid.

163 Ibid.

164 Ibid.

165 Ibid.

166 AM Greenwell, "Catholic Social Teaching: The Family, Gift and Sacntuary of Life", online: Catholic Online <https://www.catholic.org/news/hf/family/story.php?id=44434>; UCA News, "Church Leaders Pan Philippine Same-Sex Union Survey", (2019), online: <https:/www.ucanews.com/news/church-leaders-pan-philippine-same-sex-union-survey/85277>.

167 UCA News, supra note 166.

168 Ibid.

169 Ibid.

170 Ibid.

171 Republic of the Philippines, supra note 99.

172 Jonas Bagas, "Political sectarianism and the Sogie bill", online: Inquirer.net <https://opinion.inquirer.net/115918/political-sectarianism-sogie-bill>.

173 Cornelio Jayeel \& Dagle Robbin, "A prayerful Congress", (2019), online: Rappler <https://www.rappler.com/thought-leaders/236338-prayerful-philippine-congress-sogie-equalitybill>. 


\section{CONCLUSION}

From the data presented above, it is evident that homosexuality is a deeply ingrained issue in both countries. It can be surmised that the disparity in treatment of gay men in the Philippines and Indonesia stems from religious, political and cultural dimensions. Hurdles in these areas connote a negative stance in the delivery of humane and just treatment for gay men. Furthermore, the idea of being gay, despite being historically linked to both Philippine and Indonesian society, has been degraded to "psychological disorders," "comic acts" or "social dysfunction" which separates gay men from the norm, thereby affecting their desire and need for social acceptance and integration.

\section{Religion}

The dominant religious identity of Indonesia (Islam) clearly prohibits homosexuality. Religious dictums and laws specifically condemn gayness to solitude or even death, which leads gay men in Indonesia to suffer social exclusion and deprivation of basic human rights. Laden with clear punishments for transgressors, Indonesian gay's live a life filled with anxiety or worse, deny themselves the capacity to openly enjoy their sexual orientation. Meanwhile, the dominant religious identity of the Philippines (Christian) also demonstrates discontent towards homosexuality, but recently, the country has seen a decrease in adherence to these laws and instead abides by the religious mandate to "love one another." Filipinos, despite disagreeing with same-sex marriage, do not seek to undertake punitive actions made evident by the lack of religious persecution in the country. This is relatively mild compared to the treatment of homosexuals in Indonesia, yet still acts as a deterrent due to the presence of conservative politicians barring the national Anti-discrimination Bill movement. Religious barriers prove how difficult it is to traverse and maintain such an obstacle in the pursuit of equal and just treatment for all homosexual men.

\section{Politics}

Increasing tensions have risen in Indonesia's political sphere regarding homosexuality. With the absence of legalities, homosexual men in Indonesia are bound to hide their identities, live in fear of social persecution and hate crime. Recent actions such as comments from political figures ${ }^{174}$ against homosexuals in the political arena, contribute to the nationwide social rejection of gay men. In the Philippines, legislators, both conservative and radicals, are in a deadlock in terms of providing comprehensive legislative support for members of the LGBT community. However, some local

174 These Political Games Ruin our Lives" Indonesia's LGBT Community under Threat, by Human Rights Watch (2016). 
government units have taken it upon themselves to enact anti-discrimination ordinances for LGBT people. This highlights the social divide in terms of accepting LGBT individuals in to mainstream society. Corollary to this is the ambiguity of the Philippine Constitution's contents for this particular minority, which states that 'no one should be deprived of life, liberty or property without due process of law, nor shall anyone be denied of equal protection of the law, " 175 which in theory offers non-specific protection for all citizens of the country. In regards to same-sex marriage, despite most Filipinos disagreeing with the notion, the practice is alive and thriving, ${ }^{176}$ hinting at the government's lax approach in creating laws that either support or enact punitive action for the issue at hand. The passage of the proposed SOGIE Bill is yet to materialize despite undergoing numerous proceedings. This prolonged pacing places Filipino gay men who experience discrimination and abuse in peril.

On a positive note, such a level of intervention proves that both countries, despite hurdles in the political arena have been awakened to the presence of homosexual persons. The presence of human rights groups and advocates exhibit an almost healthy level of tolerance. Continued participation in legislative processes, media presence and other activities indicate that punitive actions toward homosexual people are yet to reach an irreconcilable state.

\section{Culture}

Homosexuality is tied historically to both countries' culture. Indigenous practices in prior eras of the Philippines connote deeper ties to rituals, which with the onset of the colonial period were rendered ambiguous by Christianity and the Spaniards. Homosexuality in modern Philippines persists, however, in a form that must adhere to existing stereotypes. On a similar note, the practice of Islam as the predominant religion in Indonesia, sparks concerns over the presence of homosexuality in their culture. These events could gradually strip homosexuality of its roots and footing in Indonesia, of which the general public have not been informed. Such a phenomenon raises concern for the fulfilment of human rights as well as the slow dissipation of the presence of homosexuality in its natural form.

The contrasting treatment of homosexual men between the two countries is exemplified by three dimensions. Firstly, religion dictates that homosexuality is unacceptable, be it under Christianity or Islam. Filipinos seem to lack rigor and a stringent attitude in this aspect compared to Indonesians. Secondly, Philippine politics equally lacks rigor and attitude in comparison with Indonesia, so much so that the democratic process becomes a hurdle not just for the homosexual minority but similarly for other groups. It is evident that religiously conservative political figures pose threats to

175 Rev. Agbani in R Reyes, "Same-Sex Wedding thrives in Philippines amid Opposition", (2018), online: SunstarCom <https://www.sunstar.com.ph/article/1754940>.

176 Ibid. 
homosexual men through legal sanctions or inactivity, yet these conservatives are balanced by visible human rights activists. Thirdly, despite the historic presence of homosexuality in both countries, gay men in the Philippines continue to integrate themselves within society in various forms, placing their presence to tolerable levels to its current state. Still, tolerance is simply that: tolerance, without the gusto for total acceptance or complete social integration and equity.

\section{RECOMMENDATIONS}

Extant literature suggests that acceptance is dependent upon a country'seconomic and religious status, particularly in countries that are more secular and affluent. ${ }^{177}$ This suggests the harsh treatment of gay men in Indonesia and the Philippines is to be expected. Yet contrary to these expectations is the tolerance of gay men in the Philippines, and the emerging but not yet fully developed hostility towards gay men in Indonesia. Disparity is evident but only within limited studies ${ }^{178}$ on homosexual rights in both countries. Therefore, it is recommended that scholars, researchers, activists, government and nongovernment groups and organizations conduct more comprehensive studies on homosexuality in the Philippines and Indonesia. Such studies are crucial in supporting the rights of sexual minorities.

Religious groups are recommended to uphold the value of human life. Sexual orientation is but a defining aspect of an individual's personality, a dimension that is relatively less important than their actual humanity. Punishing or discriminating against minority groups on the basis of sexual orientation removes the dignity of the people involve and such transgressions are socially counterproductive and inhumane.

Political figures must establish a common ground for human equality and remove themselves from constraints that would bar them from protecting the common good. Nevertheless, freedom of choice is a fundamental right of all people and actions in circumstances that involve choosing religion over common social good are not beyond the rights of a person. To resolve such a dilemma, it is best to practice democracy and let the people decide for themselves.

For cultural figures and organizations, it is imperative the historic presence of homosexuality in Indonesia and the Philippines be highlighted. Disseminating such information will enable the current generation to reflect and gradually accept gay men.

Lastly, humanity must be redefined in order to transition from segregation to inclusion. Classifying people according to their race, gender, religion, disability and other categories becomes an instrument of exclusion. Discrimination is born out of

177 Pew Research Center, "The Global Divide on Homosexuality: Greater Acceptance in More Secular and Affluent Countries", (2013), online: <https:/www.pewglobal.org/2013/06/04/the-global-divideon-homosexuality/>, Washington DC.

178 UNDP \& USAID, supra note 49. 
categorization, as well as human personal differences. Removing the root cause will eradicate its purported effects. Only then can the plight of gay men in both countries be alleviated.

\section{BIBLIOGRAPHY}

690 Manila. "The One 690 Entertainment Bar”, online: <http://www.690manila.com>.

Ablon, G.M. "Passage of SOGIE Bill Urged", online: Rappler <https://ribune.net.ph/index.php/2019/07/01/passage-of-sogie-bill-urged>.

AFP. "Thousands March for Equality in Manila's Pride Parade”, (2019), online: Philippine Star <https://www.philstar.com/headlines/2019/06/30/1930782/ thousands-march-equality-manilas-pride-parade>.

Alipour, M. "Shīca neo-traditionalist scholars and theology of homosexuality: review and reflections on Mohsen Kadivar's shifting approach” (2018) 24:3 Theology \& Sexuality 200-218.

Arivia, Gadis \& Abby Gina Boangmanalu. "When the State is Absent: A Study of LGBT Community in Jakarta” (2015) 4:1 Indonesian Feminist Journal 4-12.

Badinter, Elisabeth. XY : De l’identité masculine (Paris: Odile Jacob, 1992).

Bagas, Jonas. "Political sectarianism and the Sogie bill", online: Inquirer.net <https://opinion.inquirer.net/115918/political-sectarianism-sogie-bill>.

Bevins, V. "Once-Tolerant Indonesia Moves to Outlaw Gay and Extramarital Sex", The Washington Post (2018), online: <https://www.washingtonpost.com/world/ asia_pacific/once-tolerant-indonesia-moves-to-outlaw-gay--and-extramarital-sex/2018/02/09/d82b7112-0b79-11e8-998c-96deb18cca19_story.html>.

Bhandari, S. "The Best LGBTQ Bars and Clubs in Manila, Philippines”, (2018), online: Culture Trip <https://theculturetrip.com/asia/philippines/articles/the-best-lgbtqbars-and-clubs-in-manila-philippines/>.

Bilon, Xavier Javines \& C De Leon. "With no national law, can we rely on local ordinances to protect LGBTQs against discrimination?", (2018), online: cnn <https://cnnphilippines.com/life/culture/2018/06/25/antidiscrimination-billlgbtq.html>.

Boellstorff, Tom. The Gay Archipelago: Sexuality and Nation in Indonesia (Princeton University Press, 2005).

Caroll, A. State sponsored homophobia 2016: A world survey of sexual orientation laws: Criminalisations, protection and recognition, by A Caroll (Geneva: International Lesbian, Gay, Bisexual, Trans and Intersex Association, 2016). 
Castañeda, Marina. Comprendre l'homosexualité: Des clés, des conseils pour les homosexuels, leurs familles, leurs thérapeutes (Paris: Robert Laffont, 1999).

Chase. "Anti-Discrimination Ordinances Across the Philippines”, (15 May 2017), online: Transgender Philippines <http://www.transph.org/information/philippineanti-discrimination-ordinances/>.

Chiu, P. "Pinoys are gay friendly? Only on paper, says LGBT activist", (2013), online: GMA News Online <https://www.gmanetwork.com/news/news/nation/ 312328/pinoys-are-gay-friendly-only-on-paper-says-lgbt-activist/story/?fbclid=IwAR 3U6vPn7Mf18VqdFX4uWu4kq5tmSqDJO-IYSstGo1uTpFtm9WiItp6dJ1Q>.

Conde, C. "Philippines Should Adopt Same-Sex Marriage", (20 March 2017), online: Human Rights Watch <https:/www.hrw.org/news/2017/03/20/philippines-shouldadopt-same-sex-marriage $>$

Crisostomo, S. "LGUs lauded for measures on LGBT rights", (2019), online: Philippine Star <https://www.philstar.com/headlines/2019/06/25/1929308/lgus-lauded-mea sures-lgbt-rights>.

Darrow, W. W. et al. "The gay report on sexually transmitted diseases." (1981) 71:9 Am J Public Health 1004-1011.

Davies, Sharyn. "Gender diversity in Indonesia: Sexuality, Islam and queer selves" (2010) Gender Diversity in Indonesia: Sexuality, Islam and Queer Selves 1-257.

De Wilde, C. "LGBT Tourism and Inclusion in Southeast Asia: A Divided Future?", (2018), online: <https://thediplomat.com/2018/06/lgbt-tourism-and-inclusion-insoutheast-asia-a-divided-future/>.

Demetrianova, Alexandra. "The Invisible LGBT in ASEAN: Part 2", (2014), online: SimplySyx <http://simplysxy.com/articles/2014/07/05/the-invisible-lgbt-people-inasean-part-2/>.

Deslate, M.J.B. “The SOGIE Equality Bill”, (2016), online: Divina Law Dynamic Lawyering <https:/divinalaw.com/sogie-equality-bill/>.

Donovan, James M. "Homosexual, gay, and lesbian: defining the words and sampling the populations.” (1992) 24:1 Gay and Lesbian Studies (Journal of homosexuality) $27-47$.

Dowshen, S. "Sexual Orientation", (2018), online: The Nemours Foundation <https://kidshealth.org/en/parents/sexual-orientation.html>.

Emont, J. "Indonesia's Top Court Weighs Ban on Sex Outside Marriage”, Washington Post (2016), online: <https:/www.washingtonpost.com/world/asia_pacific/sex-isabout-to-get-much-more-complicated-in-indonesia/2016/10/25/e12db900-8f1511e6-a6a3-d50061aa9fae_story.html?utm_term=.6d3735229a1e>. 
Flores, A. \& A. Park. "Polarized Progress: Social Acceptance of LGBT People in 141 Countries, 1981 to 2014” (2018) The Williams Institute, UCLA School of Law, online: <https://williamsinstitute.law.ucla.edu/wp-content/uploads/PolarizedProgress-April-2018.pdf>.

Fraser, Nancy. Justice Interruptus: Critical Reflections on the "postsocialist" Condition (New York \& London: Routledge, 1997).

Gander, K. "Muslims, Jews and Christians on Being LGBT and Believing in God", (2017), online: The Independent <https://www.independent.co.uk/life-style/lovesex/lgbt-muslims-christians-jews-stonewall-beliefs-god-faith-role-models-lifestyle-gaylesbians-trans-a7666846.html >>.

Gates, Gary J \& Jason Ost. The Gay and Lesbian Atlas (Washington, D.C: Urban Institute Press, 2004).

Gates, Gary J. "LGB/T Demographics: Comparisons among population-based surveys" (2014) Williams Institute: UCLA School of Law.

Gita, RA. "SWS: 61\% of Filipinos Reject Same-Sex Marriage", (2018), online: Sunstar.com <https://www.sunstar.com.ph/article/1750492>.

Greenwell, AM. "Catholic Social Teaching: The Family, Gift and Sacntuary of Life", online: Catholic Online <https://www.catholic.org/news/hf/family/story.php?id $=44434>$.

Guitierrez, N. "LGBTQ Activists: We are Tolerated but not Accepted in the Philippines", (2017), online: Rappler <https://www.rappler.com/nation/170091lgbtq-rights-philippines-tolerated-not-accepted>.

Habib, S. Islam and Homosexuality (Santa Barbara, California: ABC-CLIO, LLC, 2010).

Hatzenbuehler, Mark L. "The Social Environment and Suicide Attempts in Lesbian, Gay, and Bisexual Youth” (2011) 127:5 Pediatrics 896-903.

Hayes, J J. “Gayspeak” (1976) 52 Quarterly Journal of Speech 256-266.

Herek, Gregory M \& Kevin A McLemore. "Sexual Prejudice” (2013) 64:1 Annual Review of Psychology 309-333.

Herek, Gregory M. "Beyond 'homophobia': Thinking about sexual prejudice and stigma in the twenty-first century" (2004) 1:2 Sexual Research \& Social Policy 6-24.

—_. "Confronting sexual stigma and prejudice: Theory and practice" (2007) 63 Journal of Social Issues 905-925.

—_. "Facts About Homosexuality and Child Molestation”, (2018), online: UC Davis <https://psychology.ucdavis.edu/rainbow/html/facts_molestation.html>. 
Human Rights Watch. These Political Games Ruin our Lives” Indonesia's LGBT Community under Threat, by Human Rights Watch (2016).

Jayeel, Cornelio \& Dagle Robbin. “A prayerful Congress”, (2019), online: Rappler $<$ https://www.rappler.com/thought-leaders/236338-prayerful-philippine-congresssogie-equality-bill>.

Jennings, R. "These Asian Countries are the Most Likely to Follow in Taiwan's LGBT Rights Footsteps” Forbes (2017), online: <https://www.forbes.com/sites/ ralphjennings/2017/05/25/after-same-sex-marriage-in-taiwan-spotlight-turns-to-thisasian-country/\#561a39613b4f>.

Johan, Rizki Theodorus. "Discovering the 'Others': Unearthing Homosexual Identity Construction in Selected Indonesia Contemporary Novels and Short Stories” (2011) Proceedings The Asian Conference on Literature and Librarianship.

Kartomi, Margaret. "Performance, Music and Meaning of ReyogPonorogo" Indonesia (1976).

Kinsey, Alfred C, Wardell R Pomeroy \& Clyde E Martin Sexual. "Sexual Behavior in the Human Male" (2003) 93:6 American Journal of Public Health 5.

Klein, R. "Markova: Wartime Comfort Gay in the Philippines. Interview with Walter Dempster Jr” (2006) Intersections, online: <http://intersections.anu .edu.au/issue13/klein_interview.html>.

Langlois, A et al. "LGBT Rights in Southeast Asia: One Step Forward, Two-Steps Back?” (2017) IAFOR Journal of Asian Studies, online: <http://iafor.org/ archives/journals/iafor-journal-of-asian-studies/10.22492.ijas.3.1.01.pdf $>$.

Langlois, Anthony J. et al. "Community, identity, orientation: sexuality, gender and rights in ASEAN” (2017) 30:5 The Pacific Review 710-728.

Lemke, Richard, Tobias Tornow \& PlanetRomeocom. Gay Happiness Monitor Results overview from a global survey on perceived gay related public opinion and gay well-being (Mainz: Johannes Gutenberg University, 2015).

Magsambol, B. "Record Breaking: 70,000 Filipinos join Metro Manila Pride 2019", (2019), online: <https:/www.rappler.com/move-ph/234225-metro-manila-pride2019-attendees-breaks-record>.

Manalastas, Eric Julian \& Beatriz Torre. "Social Psychological Aspects of Advocating LGBT Human Rights in the Philippines" University of the Philippines, online: $<$ https://pages.upd.edu.ph/sites/default/files/ejmanalastas/files/manalastas_torre_fil _lgbt_activism.pdf>.

Manalastas, Eric Julian. “Anti-Discrimination Ordinances” (2015) Department of Psychology, University of the Philippines, online: <https://pages.upd.edu.ph/ ejmanalastas/policies-ordinances>. 
—. "Homonegativity in Southeast Asia: Attitudes Toward Lesbians and Gay Men in Indonesia, Malaysia, the Philippines, Singapore, Thailand, and Vietnam” (2017) 17:1 Asia-Pacific Social Sciences Review 25-33.

Marcus, J. "5 LGBT-Friendly Cities in South-East Asia” Goats on the Road.”, (2018), online: <https://www.goatsontheroad.com/lgtb-friendly-southeast-asia/>.

Masci, David \& D. Desilver. "Gay Marriage Around the World” Pew Research Center.”, (2019), online: <https://www.pewresearch.org/fact-tank/2019/06/21/globalsnapshot-same-sex-marriage/>.

Masli, N. "Being LGBT in Indonesia, Why Attacks on the Community are Growing", (2018), online: Lifegate <https://www.lifegate.com/people/news/lgbt-in-indonesiaattacks-increasing>.

McLaughlin, Katie A., Mark L. Hatzenbuehler \& Katherine M Keyes. "Responses to Discrimination and Psychiatric Disorders Among Black, Hispanic, Female, and Lesbian, Gay, and Bisexual Individuals” (2010) 100:8 American Journal of Public Health 1477-1484.

Merigo, E. "In Indonesia, LGBT Communities Viewed as a Moral Threat Condemned by Religion and, increasingly, by Law" South China Morning Post (7 April 2019), online: <https://www.scmp.com/magazines/post-magazine/longreads/article/3004634/indonesia-lgbt-community-viewed-moral-threat $>$.

Mucherah, Winnie, Elizabeth Owino \& Kaleigh McCoy. "Grappling with the issue of homosexuality: perceptions, attitudes, and beliefs among high school students in Kenya” (2016) 9 Psychology Research and Behavior Management 253-262.

Murtagh, Ben. Genders and Sexualities in Indonesian Cinema. Construction of gay, lesbi and waria identities on screen (New York: Routledge, 2013).

NQAPIA. "Fact Sheet: The State of LGBTQ Rights in Asia and the Pacific", (12 February 2018), online: National Queer Asian Pacific Islander Alliance <https://www.nqapia.org/wpp/state-of-lgbtq-rights-in-asia-and-the-pacific/>.

Offord, Baden. "Singapore, Indonesia and Malaysia: Arrested Development!" in Manon Tremblay, David Paternotte \& Carol Johnson, eds, The Lesbian and Gay Movement and the State Comparative Insights into a Transformed Relationship (Ashgate, UK: Routledge, 2011).

OHCHR. Born free and equal: Sexual Orientation and gender identity in international human rights law (New York: United Nations, 2012).

Pascual, G.R. "Sward Speak (Gay Lingo) in The Philippine Context: A Morphological Analysis" (2016) International Journal of Advanced Research in Management and Social Sciences, online: 〈http://www.garph.co.uk/IJARMSS/Dec2016/4.pdf>. 
Pew Research Center. "The Global Divide on Homosexuality: Greater Acceptance in More Secular and Affluent Countries", (2013), online: <https://www.pewglobal.org/2013/06/04/the-global-divide-on-homosexuality/>.

Pollack, Lance M. et al. "Presence of an HIV Testing Program Lowers the Prevalence of Unprotected Insertive Anal Intercourse inside a Gay Bathhouse among HIVnegative and HIV-unknown Patrons.” (2014) 13:3 Journal of HIV/AIDS \& Social Services 306-323.

Presidential Museum and Library. "Pre-Colonial Manila", online: Malacanang Palace <http://malacanang.gov.ph/75832-pre-colonial-manila/>.

Psychological Association of the Philippines. Reaffirmation of Non-Discrimination of LGBT Filipinos (2013).

Rainbow Rights Project \& Philippine LGBT Hate Crime Watc. The Status Of Lesbian, Gay, Bisexual And Transgender Rights In The Philippines: Submission to the Human Rights Council for Universal Periodic Review 13th Session (Universal Periodic Review, 2012).

Ramadhani, N.F. \& I. Parlina. "Anti-LGBT Rhetoric to Spike Ahead of Elections”, The Jakarta Post (2016), online: <https://www.thejakartapost.com/news/2016/08/12/antilgbt-rhetoric-spike-ahead-elections.htm>.

Rapplercom. "How Religious Groups Clashed over LGBTQ+ Rights at Pride 2019", (2019), online: <https://www.rappler.com/move-ph/234350-how-religious-groupsclashed-lgbtq-rights-pride-march-2019>.

—. "Look: Stars, Beauty Queens at Metro Manila Pride 2019", (2019), online: <https://www.rappler.com/entertainment/news/234238-photos-celebrities-beautyqueens-manila-pride-2019>.

Republic of the Philippines. "House Bill No. 4982: An Act Prohibiting Discrimination on the Basis of Sexual Orientation or Gender Identity or Expression (SOGIE) and Providing Penalties Therefore”, online: <http://www.congress.gov.ph/legisdocs/first_17/CR00101.pdf>.

Reyes, R. "Same-Sex Wedding thrives in Philippines amid Opposition", (2018), online: SunstarCom <https://www.sunstar.com.ph/article/1754940>.

Ricordeau, G. "Review: Philippine Gay Culture: Binabae to Bakla, Silahis to MSM" (2009) 19 Intersections: Gender and Sexuality in Asia and the Pacific, online: <http://intersections.anu.edu.au/issue19/ricordeau_review.htm>.

Rivera, A. "Marikina Ordinance Upholds LGBT Community Equal Right” (2019) People's Journal, online: <https://journal.com.ph/news/metro/marikina-ordinanceupholds-lgbt-community-equal-rights>.

Robison, J. "What Percentage of the Population is Gay?”, (2002), online: Gallup Inc <https://news.gallup.com/poll/6961/what-percentage-population-gay.aspx>. 
Rukmana, D. "The Megacity of Jakarta: Problems, Challenges and Planning Efforts”, (2014), online: Indonesia's Urban Studies <http://indonesiaurbanstudies. blogspot.com/2014/03/the-megacity-of-jakarta-problems.html>.

Sanders, Douglas. "Recognizing Same-Sex Relationships in Thailand" (2013) 6:1 CMU Journal of Law and Social Sciences 27-55.

Sapiie, Marguerite Afra. "LGBT people viewed negatively, but accepted as Indonesian citizens", The Jakarta Post (25 January 2018), online: <https://www. thejakartapost.com/news/2018/01/25/lgbt-followers-viewed-negatively-but-acceptedas-indonesian-citizens.html>.

Savin-Williams, Ritch C. The New Gay Teenager. (Cambridge: Harvard University Press, 2005).

Siker, Jeffrey S. Homosexuality and Religion: An Encyclopedia (Westport, Conn: Greenwood Press, 2006).

Solomon, M. \& K. Mayer. "Evolution of Syphilis Among Men Who Have Sex with Men” (2015) 12:2 Sexual Health 96-102.

Spiegelhalter, D. "Is $10 \%$ of the Population Really Gay?", (2015), online: <https://www.theguardian.com/society/2015/apr/05/10-per-cent-population-gayalfred-kinsey-statistics>.

Tákacs, Mocsonaki \& Tamás P Tóth. Social Exclusion of Lesbian, Gay, Bisexual and Transgender (LGBT) People in Hungary, Research Report, by Mocsonaki Tákacs \& Tamás P Tóth, Research Report (Institute of Sociology, Hungarian Academy of Science, 2008).

Tan, M.L. "Survival through pluralism: emerging gay communities in the Philippines." (2001) 40:3-4 Journal of Homosexuality 117-142.

The 1987 Constitution of the Republic of the Philippines. Art. III. Bill of Rights., (1987).

The Office of Lesbian, Gay, Bisexual, Transgender, Queer \& Intersex Life. "Definitions", online: Vanderbilt University <https://www.vanderbilt. edu/lgbtqi/resources/definitions>.

Thin, R. N. \& D. M. Smith. "Some characteristics of homosexual men" (1976) 52:3 The British Journal of Venereal Diseases (Sexually Transmitted Infections) 161-164.

Thoreson, R. \& D. Lee. Just Let Us Be: Discrimination against LGBT Students in the Philippines, by R Thoreson \& D Lee (USA: Human Rights Watch, 2017).

Tubeza, Philip C. "PH ranks among most gay-friendly in the world", online: InquirerNet $<$ https://globalnation.inquirer.net/76977/ph-ranks-among-most-gay-friendly-in-theworld $>$. 
UCA News. "Church Leaders Pan Philippine Same-Sex Union Survey”, (2019), online: $<$ https://www.ucanews.com/news/church-leaders-pan-philippine-same-sex-unionsurvey/85277>.

UNDP \& USAID. Being LGBT in Asia: The Philippines Country Report, by UNDP \& USAID (Bangkok, 2014).

United Nations. The World's Cities in 2016, by United Nations (2016).

Waters, M. "The First Pride Marches in Photos" SmithsonianCom (2019), online: <https://www.smithsonianmag.com/history/first-pride-marches-photos-1-18097 2379/?utm_source=facebook.com\&utm_medium=socialmedia\&fbclid=IwAR3uf1p uFi6KrCfBqKil6Qwo__pfxvVW0VqawQJiD5CTNk91pvZzmGvci4Q>.

Whitaker, Brian. Unspeakable Love (London: SAQI, 2011).

Whitaker, Robyn. "Same Sex Marriage: What Does the Bible Really Have to Say?”, Australian Broadcasting Corporation (2017), online: <https://www.abc.net. au/news/2017-08-23/same-sex-marriage-what-bible-has-to-say-robyn-whitaker/ 8831826>.

Widianto, S. "LGBT Jakartans: Worse than a Nuclear Bomb. We Just Want to be Accepted", (2016), online: <https://www.theguardian.com/cities/2016/nov/26/lgbtyoung-jakartans-nuclear-bomb-accepted $>$.

Wilson, Ian Douglas. "ReogPonorogo: Spirituality, Sexuality and Power in a Javanese Performance Tradition” (1999) 2 Intersections: Gender and Sexuality in Asia and the Pacific, online: <http://intersections.anu.edu.au/issue2/Warok.html>.

Yee, H.Y. LGBT Rights in South Asia: What Next?, by HY Yee (Salzburg, Austria: Salzburg Global Seminar, 2019).

Yosephine, L. "Indonesian psychiatrists label LGBT as mental disorders", The Jakarta Post (2016), online: <https://www.thejakartapost.com/news/2016/02/24/indonesianpsychiatrists-label-lgbt-mental-disorders.html>.

Wisnu Adihartono is Ph.D in sociology (gender, migration, family, everyday life, Southeast Asian Studies) from École des Hautes Études en Sciences Sociales (EHESS), France. He lives in Jakarta and works as a sociologist and independent researcher. He will be a visiting researcher at Centre for Southeast Asian Studies, National Chi Nan University (NCNU), Taiwan.

Ellisiah U. Jocson Holds a degree in Special Education from Far Eastern University. His primary research interests includes people with disabilities and other minority groups in 
the Philippines. He lives in Marikina and currently works as the Department Head of a non-government organization (NGO). 